\title{
One Step Forward, Two Steps Back: Boris Yeltsin and the Failure of Shock Therapy
}

Christopher Huygen

\begin{abstract}
The collapse of the Soviet Union created unprecedented dilemmas for the leaders of the new independent Russia. Shedding the communist past, Boris Yeltsin embarked on an ambitious program to reorganize Russia's political and economic systems. Known as 'shock therapy,' Yeltsin advocated a rapid transition from state planning to a market economy while simultaneously introducing democracy to Russia. Expecting a short period of hardship as economic reforms opened Russia to world markets, followed by prolonged growth and prosperity, Yeltsin's societal upheaval left Russia a prostrate state, mired in a depression that left many longing for a return to socialism.
\end{abstract}

This paper argues that the economic policies of shock therapy were an unmitigated failure. Four overarching factors will be analyzed to provide a foundational understanding of the social, economic, and international circumstances that made shock therapy's methods ineffective. Adopted before Russia was institutionally and politically prepared, the simultaneous transition to capitalism and democracy hindered the Russian state's ability to ensure a stable atmosphere to conduct business, while old guard communists obstructed progress by resisting radical change. Economic instability engendered by shock therapy reverberated throughout Russian society, creating political anxiety and lowering living standards that undermined the popular support crucial to the program's success. Shortsighted policies and inept privatization practices allowed a small conglomerate of business elites to gain control of Russia's most profitable industries, creating a class of oligarchs uninterested in reinvesting capital but skilled in circumventing Russia's tax laws. Lastly, the involvement of the international community, primarily comprised of Western nations and the International Monetary Fund (IMF), disrupted Russia's development by setting strict conditions on their loans and committing insufficient amounts that ultimately created more problems than they solved.

With a history devoid of democracy or capitalism in Russia, the envisioned aims of shock therapy were impossibly unrealistic. Underlying the failure of market reform was the leadership of Boris Yeltsin, whose actions to maintain his political standing (particularly the reintroduction of state subsidies), undermined the gains made through shock therapy's policies. As high unemployment and declining wages led opposition groups to challenge his power, Yeltsin reverted to increasingly authoritarian tactics to consolidate his position as president amidst a revolving door of prime ministers. Presiding over a tenuous government beset with nationalist tensions and persistent inefficiencies from the Soviet period, Yeltsin's top down economic reforms failed to create economic stability or nurture small business growth. These downward trends culminated in the 1998 financial crisis, when radical measures to devalue the ruble and rising natural resource prices brought economic recovery to Russia for the first time since shock therapy's implementation. By the end of Yeltsin's 
political career, Russia was neither democratic nor truly capitalist, but a remodeled version of Russia's authoritarian past, a trend sustained and strengthened in the Putin Era.

\section{New Economic Policy}

When Yeltsin assumed power in 1991, he inherited a stagnant economy mired in corruption and inefficiency. Earlier attempts to reform the Soviet system under Gorbachev, including the 500-Days program, had failed or been abandoned, as plans to create a middle ground between a state and market economy were no remedy for the Soviet Union's excessive military spending, inefficient bureaucracy, and technological weakness. Yeltsin had consistently supported radical economic reforms through the late Soviet period, and made the economy his top priority for the new Russian Federation. With extraordinary powers from the Congress of People's Deputies and an inner circle of reformist deputies including Yegor Gaidar, Anatoly Chubais, and Gennady Burbulis, the Yeltsin government began shock therapy initiatives on January 2, 1992. Shock therapy was based on five pillars of reform: liberalization of prices, control over money and credit, eliminating budget deficits, opening Russia to foreign-direct investment and privatizing business. Shock therapy's fortunes were dependent on the political clout and popular appeal, and Yeltsin tied his political prestige to the success of these new economic policies. ${ }^{1}$ Warning the population to prepare for six months of hardship, the Yeltsin administration believed that an upheaval of the entrenched Soviet system could be accomplished by a rapid leap forward, followed by a replenished consumer market, rejuvenated work force, and overall increase in the standard of living. "If we enter on this path today, we will have concrete results by the fall of 1992," Yeltsin promised, "If we do not take a concrete step to break the unfavorable course of events, we will doom ourselves to poverty, and doom a state with a history of many centuries to collapse."2

Simultaneously, Russia was adjusting to democracy, an unfamiliar concept to most Russians, and just beginning to develop state institutions distinguishable from the Soviet past. Despite the presence of foreign economists and well-placed reformers, an extraordinary amount of continuity existed between the Soviet era and the young and unstable Russian democracy. The majority of Congress deputies, business elites, and factory owners were products of the Communist system and hesitant to change. ${ }^{3}$ Facing difficulty from Communist holdovers, Yeltsin considered a speedy transformation essential to prevent a resurgence of Soviet authority and definitively move Russia away from the Communists' economic and political agenda. However, this meant introducing economic reforms before Russia was institutionally capable of guaranteeing the protection of capital, rule of law, or industrial profitability. ${ }^{4}$ Seeing an opportune moment in the public frenzy caused by the Soviet Union's collapse, the Yeltsin administration believed the chaotic political atmosphere would sanction greater tolerance amongst the population to accept the high prices and inflation of a free market transition. In a politically expedient move, Yeltsin hoped to ride this wave of euphoria and undercut parliamentary dissent, limiting the potential damage shock therapy could do to his

${ }^{1}$ R.G. Gidadhubli and Arun Mohanty, "Continuing Debate over 'Shock Therapy," Economic and Political Weekly 37.50 (2002): 4999.

2 Serge Schmemann, "Yeltsin Is Telling Russians To Brace For Sharp Reform," The New York Times, October 29, 1991.

${ }^{3}$ Herbert J. Ellison, Boris Yeltsin and Russia's Democratic Transformation (Seattle: University of Washington Press, 2006), 73-74.

4 Mark Kesselman et al. (eds.), Introduction to Comparative Politics: Global North (Custom Edition. Boston: Wadsworth, 2010), 325-326. 
leadership. This accelerated timeline meant shock therapy was initiated before Russia's political and financial institutions had sufficiently become established and legitimized to allow the program's success. ${ }^{5}$

The inability of state institutions to enforce law and order, collect taxes, and maintain infrastructure impeded Russia's progression to free-market economics, while the instability of Yeltsin's political position led to increasing conflicts with parliament and a steady stream of defections from the Yeltsin administration. By introducing market reforms, Yeltsin's control of society was loosened, and the weakened power of the state made Russia vulnerable to new forms of corruption and criminality. ${ }^{6}$ When economic recovery did not begin as expected, patience with reforms eroded and criminal activity proliferated. An atmosphere of lawlessness consumed Russia as legal institutions and legislative jurisdiction were de-legitimized by Yeltsin's emergency decrees and strongman tactics, undermining the democratic authority of the state and respect for the rule of law. ${ }^{7}$ Russia's short democratic history and fluid political procedures allowed Yeltsin to concentrate power in the office of the presidency, diluting the power of the parliament and initiating a democratic backslide into authoritarianism. A weak system of checks and balances to prevent the accumulation of power and a political culture accustomed to centralized government under a despotic leader enabled Yeltsin to usurp political authority amidst the social crisis created by shock therapy.

Fearing social unrest and political instability, foreign investors' trust in the new Russia waned, and many withheld capital, depriving the state of badly needed revenue. Small business enterprises were hamstrung by bureaucratic process, hindering the growth of the private sector. ${ }^{8}$ Illegal businesses, closely tied to organized crime syndicates, filled this vacuum in the consumer market, avoiding Russian regulations and tax laws by smuggling in foreign goods. ' As the Russian state could ensure neither property rights nor the enforcement of contracts crucial to the development of a market economy, foreign investment stalled, while the absence of stable financial institutions and weak market for domestic goods threatened to ruin Russia's largest industrial enterprises. Fearing even greater unrest and unemployment than was already paralyzing Russia, the Yeltsin administration intervened in the economy to subsidize unprofitable industries, undermining the free-market premises of shock therapy.

The transformation of the Russian economy was encumbered by the economic structures of the Soviet past. The Cold War arms race created an imposing military-industrial complex, employing millions of skilled laborers whose expertise building aircraft, submarines, and tanks was incongruous with the aims of the new Russia. Shifting away from a heavily militarized economy, defense budgets were slashed, provoking the ire of military and KGB leaders mourning Russia's declining prestige, though many defense industries were kept on the government payroll, diverting spending from social welfare programs or stimulative

\footnotetext{
${ }^{5}$ Lynn D. Nelson and Irina Y. Kuzes, Radical Reforms In Yeltsin's Russia: Political, Economic, and Social Dimensions (New York: M.E. Sharpe, 1995), 18.

${ }^{6}$ Lilia Shevtsova, Russia-Lost in Transition: The Yeltsin and Putin Legacies (Washington, DC: Carnegie Endowment for International Peace, 2007), 3.

${ }^{7}$ Mitchell Orenstein, "Lawlessness From Above and Below: Economic Radicalism and Political Institutions," SAIS Review 18.1 (1998): 36.

8 Mark Kramer, "The Changing Economic Complexion of Eastern Europe and Russia: Results and Lessons of the 1990s," SAIS Review 19.2 (1999): 26.

${ }_{9}$ Charles E. Ziegler, The History of Russia, 2nd ed. (California: Greenwood Press, 2009), 154.
} 
economic initiatives. ${ }^{10}$ This was a common scenario involving former state owned enterprises, still operating under command economy mindsets, that impelled Yeltsin to resume subsidies to many of Russia's largest and least profitable industries. Rather than allow unprofitable businesses to fail, as market ideology dictates, the introduction of subsidies and renationalization of industrial and agricultural enterprises undercut the reform program while failing to solve the inherent problems of the economy. ${ }^{11}$

What was designed as a politically expedient way to transform Russia's economy and maintain popular support for Yeltsin was successful in neither respect. However, Yeltsin defended his actions in a 2003 interview, disputing an article that stated he would have been a great president if he hadn't launched privatization. "That is not true," Yeltsin retorted, echoing his aforementioned 1991 edict, "if I hadn't launched it, we would still be saddled with a ruined economy." 12 Compromised by time and memory, Yeltsin's obstinacy belies the weak leadership and economic alternatives to immediate liberalization that would have eased the process to genuine reform.

Under shock therapy, the economy evolved into a hybrid of private enterprise controlled by a small wealthy elite, with remnants of Soviet inefficiency and production mentalities that was sustained by a vibrant black market. A graduated process of reform, with free market policies introduced before political freedoms, similar to China's path to economic liberalization, would have offered a more moderate way to ensure that stable state institutions and economic growth were in place before nation building could begin, preventing the social unrest and government weakness that threatened to destabilize Yeltsin's ruling regime.

\section{A Bad Economy Breeds Instability}

The success of shock therapy relied on the support of the Russian population. Implemented by decree, Yeltsin gambled that his popular appeal would sustain support through tough conditions. Economic planners warned that lifting price controls and opening Russia to world markets would temporarily create high prices for consumer goods, cause wages to decline, and require cuts to social welfare programs, asking citizens to endure six months of adversity for future prosperity. The consequences were worse than expected: food prices rose $400 \%$ in a month, inflation rose $2500 \%$, and real wages failed to keep up with the cost of living. ${ }^{13}$ Unemployment, rare in the Soviet period, swelled, while the social safety net guaranteeing basic access to health care, education, and pensions for elderly Russians evaporated as efforts to eliminate budget deficits depleted social spending, leaving many Russians nostalgic for the Soviet past. Hyperinflation decimated Russians' savings and limited businesses' ability to pay their workers, leading many enterprises to resort to bartering schemes to support their employees. ${ }^{14}$ The prolonged economic decline tested Russian patience, breeding instability and giving fodder to shock therapy's political opponents. Communist and nationalist forces in parliament capitalized on this sentiment, accusing Yeltsin of secret collaboration with the west and holding Gaidar and Chubais

\footnotetext{
10 Peter Reddaway, "Instability and Fragmentation," Journal of Democracy 5.2 (1994): 17-18.

${ }^{11}$ Lilia Shevtsova, Yeltsin's Russia: Myths and Reality (Washington: Carnegie Endowment for International Peace, 1999), 42.

12 Padma Desai, Conversations on Russia: Reform from Yeltsin to Putin (New York: Oxford University Press, 2006), 80.

${ }^{13}$ David Marples, "Russia Emerges From The Ruins," University of Alberta lecture, Edmonton. 2 March 2011.

14 Ziegler, History of Russia, p. 153.
} 
personally responsible for the failed reforms. Underestimating the potential human costs of economic reform, a prolonged depression eroded public support for shock therapy and magnified instability in Russian politics and society.

The early results of shock therapy caused great anger and hardship, leading Yeltsin, whose political future was tied to shock therapy's success, to distance himself from the policies of Gaidar, who became a focal point for popular discontent. In response to the growing tide of dissent, Yeltsin deflected government attention from the economy, the most important vehicle for pacifying unrest, to political matters. Former allies, including Vice President Rutskoi, joined by industrial, agrarian, and civic unions rallied against the Yeltsin administration, while a revived Communist Party brought political pressure to amend shock therapy's methods. ${ }^{15}$ Seeking to appease political opponents and prevent a popular uprising, Yeltsin acquiesced to rivals' demands and reintroduced subsidies to failing enterprises and the agricultural sector. With private land ownership, unemployment, and non-payment of wages becoming focal points of dissent, concessions to keep underemployed workers on factory payrolls and loosen tax demands on businesses placated the opposition but did nothing to solve the root of Russia's economic problems.

The social problems plaguing Russia in the shock therapy era extended beyond food shortages and depreciating living standards, exacerbating social ills suppressed in the Soviet era. Russian society became stratified between the very rich, the benefactors of privatization, and the poverty-stricken working classes. ${ }^{16}$ Beggars appeared on Russian streets, refugees from the republics migrated to urban centers, and alcoholism, a continuous problem, proliferated as cuts to social welfare programs created vagrancy and destitution amongst Russia's most vulnerable social groups. Life expectancies dropped from Soviet times, birth rates declined, and health care services eroded as poor diets, lifestyles, and work conditions became major social problems for Russia's poverty stricken population, with little recourse to high-quality medical treatment. ${ }^{17}$ Social degradation evolved into gang violence, drug use, and teenage transience, while the state, paralyzed by political infighting and inefficient tax collection services, could offer only minimal support. A clear correlation can be made between higher mortality rates and the implementation of shock therapy, as social safety nets folded under economic pressures precisely when they were most needed. ${ }^{18}$

Higher education, free for students during the Soviet period with guarantees of a job after graduation, was victimized by budget cuts, forcing students to cover the costs of tuition and books. Neglect for school improvements and inadequate wages for teachers also hindered opportunities for young Russians to receive proficient schooling. Mirroring the economic disparity of society, private schools were established for the children of wealthy 'New Russians,' providing high quality education, while the majority of working-class Russians, unable to cover school fees, were priced out of their means by the inflated prices of shock therapy. ${ }^{19}$ A universal assurance in Soviet times, even education became associated with elitism and privilege in Yeltsin's new Russia.

15 Timothy J Colton, Yeltsin: A Life (New York: Basic Books, 2008), 242-243.

16 Gidadhubli and Mohanty, "Continuing Debate," 5002.

17 Ziegler, History of Russia, p. 157.

18 "Mass Murder and the Market" The Economist. Jan. 22 2009, http://www.economist.com/node/129726 77.

19 Ziegler, History of Russia, p. 156-157. 
Omnipresent in the social failures of the Russian state was the failure of Yeltsin's leadership. A shadow of the strong-willed, populist image he cast defying the planners of the August coup, Yeltsin became withdrawn as economic recovery stalled and his political approval waned. Dismissing loyal appointees associated with shock therapy, Yeltsin continued accumulating presidential power to counteract an increasingly assertive parliament, alienating former supporters with his authoritarian tendencies. Culminating in the shelling of Parliament on 4 October 1993, Yeltsin reinforced the power of the presidency as undisputed head of state, but later withdrew from the political spotlight as health issues and disillusionment with shock therapy transformed the president into a distant, despondent figure. Troubled by inflation, poverty, and corruption, still endemic several years after shock therapy's introduction, Yeltsin's apathetic response to the plight of the Russian people and erratic behavior in government, constantly reorganizing his administration, denied shock therapy the strong leadership needed to elevate the population in times of hardship. Complicated by an unpopular, costly war in Chechnya, the political momentum of Yeltsin's earlier tenure had, with support for shock therapy, all but evaporated. In dire need of capital to replenish state coffers, economic strategists turned to poorly planned stopgap solutions, exemplified in the 'loans for shares' scheme. Unelected, notorious oligarchs from Russia's business elite, already well entrenched in powerful positions in the new Russian economy, emerged to fill the power vacuum, wielding enormous political influence through their economic eminence. ${ }^{20}$

\section{Mass Privatization and The Rise of the Oligarchs}

Despised by the suffering Russian masses, the presence of oligarchs undermined the possibilities for a true capitalist system to form. With Moscow's streets lined with Mercedes while beggars scrounged meals from garbage dumpsters, the rise of oligarchs exemplified the stratification of post-communist Russian society. Beginning in the late perestroika period and continuing through the rapid privatization of shock therapy, small factions of Communist insiders and well-connected businessmen took advantage of their privileged positions to gain ownership of key Russian industries and state property at below market prices. ${ }^{21}$ Using their political associations, Russian business elites made huge fortunes in short periods of time, gaining control of energy, banking, and natural resource companies, some of the few legitimate enterprises capable of turning profits in the shock therapy era. However, privatization as originally planned by Chubais was designed to disperse ownership amongst the Russian population. Distributing privatization vouchers, each worth 10,000 rubles, Russians were encouraged to purchase shares in newly privatized industries. Factory owners and workers were given the opportunity to purchase controlling shares of their business though, often resulting in unscrupulous managers allocating the bulk of shares for themselves or buying workers out. ${ }^{22}$ Despite owning shares in their business, the privatization voucher scheme had little effect on worker productivity or profitability, as embezzlement prevented capital from being invested to improve productivity and lax Soviet era work discipline prevailed.

Acting both as a counter-weight to a Communist resurgence and a means for citizens to become stock owners and acquire future wealth, the voucher privatization program proved popular amongst the Russian people, but accomplished little in stimulating economic

${ }^{20}$ Gidadhubli and Mohanty, "Continuing Debate," 5001.

${ }^{21}$ Shevtsova. Russia-Lost in Transition, 104-105.

${ }^{22}$ Kesselman, Comparative Politics, p. 324. 
growth. Many vouchers were sold to foreign investors, while cynicism about the declining value of the ruble and distrust in the stock market kept investment in Russian industry slow. ${ }^{23}$ Known as joint-stock companies, the mass privatization of state-owned enterprises failed to improve the Russian economy, continuously hampered by a lack of capital and investment. Wealthy Russians preferred to invest outside of Russia in the more stable markets of Western Europe, while the massive profits generated by oligarchs were sheltered in foreign banks. Nevertheless, nearly 80 per cent of medium and large state enterprises were privatized by $1994 .^{24}$ Small business, an area shock therapy planners hoped to develop into an integral part of Russia's market economy, proliferated, with over 100,000 enterprises privatized by $1994 .{ }^{25}$ Though the number of small businesses rapidly escalated, high tax rates, confusing regulations, and competition from the black market kept the economic impact of small business minimal.

Mass privatization was successful in taking most industries off government books by the mid-1990s, but economic recovery remained elusive, and the Russian state was desperate for incoming revenue. Under the initiative of Chubais, the Russian state transferred lucrative enterprises still under state control, primarily mineral and petroleum corporations, to commercial banks in exchange for loans to help the impoverished state budget. Limiting competition to Russian business elites with government connections, shares in important industries, including nickel smelting company Norilsk Nickel and oil giants Sibneft and Yukos, were loaned at discount prices. Though temporarily resuscitating the state's cash reserves, oligarchs gained control of these shares when their loans could not be repaid, solidifying the cozy relationship between government and business. ${ }^{26}$ "It was absolutely fantastic," Chubias reminisced of his controversial program, specifically referencing the sale of Norilsk Nickel shares, "It helped the federal budget a lot because the budget situation was critical." ${ }^{27}$ Despite the ephemeral solvency the loans-for-shares scheme engendered, its longterm effects compromised Russia's economic integrity and political legitimacy.

With interests in energy, banking, and the media, oligarchs' influence became ubiquitous in Russian society and politics. Threatening any democratic gains made since the fall of communism, the power of the oligarchs was most strongly felt during the 1996 presidential election. Uniting to finance Yeltsin's re-election campaign, oligarchs used their monetary and media means to maintain favor within the administration, and were rewarded with political positions. ${ }^{28}$ Subverting the democratic integrity of Russia's elections, oligarchs gained political influence and manipulated state apparatuses through strategically placed campaign funds, engineering Yeltsin's successful campaign despite failing health, dismal approval ratings and a sluggish economic track record. "The state's administrative resources swung into action in these elections in just the same way as in the Soviet period," wrote

${ }^{23}$ Padma Desai, Conversations on Russia: Reform from Yeltsin to Putin (New York: Oxford University Press, 2006), 35.

${ }^{24}$ Kesselman, Comparative Politics, 324.

25 Ziegler, History of Russia, 152.

${ }^{26}$ Lynn D. Nelson and Irina Y. Kuzes, Radical Reforms In Yeltsin's Russia: Political, Economic, and Social Dimensions (New York: M.E. Sharpe, 1995), 105.

27 Desai, Conversations on Russia, 90.

${ }^{28}$ Lilia Shevtsova, Yeltsin's Russia: Myths and Reality (Washington: Carnegie Endowment for International Peace, 1999), 161. 
controversial journalist Anna Politkovskaya, "this was also true in no small measure of the election in 1996 . . in order to get Yeltsin elected, even though he was ill and decrepit." 29

The true benefactors of the rapid privatization schemes of shock therapy, massive profits made by the oligarchs did little to help the Russian economy. Wealth failed to trickle down through the Russian population, while shortsighted policies and the absence of competition during privatization deprived the state of potential sources of revenue for quick-fix cash influxes. The development of a Russian middle-class was stunted, with society divided between very rich New Russians, living lavishly and protected by private armies, and very poor working classes, experiencing first hand the inequalities of capitalism. ${ }^{30}$ However, Russia's shock therapy policies were not isolated from the affects of globalization, and the economic problems of shock therapy must not be attributed solely to domestic forces, as the influence of international organizations had disruptive effects on Russia's economic transformation.

\section{International Intervention}

Since its inception, Western influence pervaded shock therapy planning. Stronger ties with the West and an end to the antagonistic relationship with the United States was indicative of Russia's exigent need for foreign assistance to support its transition to free markets. Consulting with Western intellectuals, most prominently economists Jeffrey Sachs and Ander Asslund, Russia was encouraged to take swift steps in overhauling its economic system, rejecting the gradual approach modeled by China. ${ }^{31}$ Bolstered by successful experiments in Bolivia and Poland, Sachs helped shape Gaidar's liberalization plans, but failed to recognize the nuances of the Russian state, whose economic structure was shaped by 70 years of state planning, a truculent military-industrial complex, and a culture unfamiliar with capitalism. $^{32}$

Dependent on significant loans from the International Monetary Fund (IMF) and international financial institutions, Sach's plan advocated tough restrictions on foreign money transfers, providing safeguards for wealthy countries to invest but creating difficult conditions for the Russian state to meet. "The IMF is in the situation of a whipping boy," Gaidar later articulated, questioning the international organization's handling of Russia's situation. ${ }^{34}$ However, Gaidar did not place blame solely on the shoulders of the global community, stating, "the problem was the absence of a clear, liberalization strategy in terms of which to define a policy framework in those days." ${ }^{35}$ Nevertheless, tentative international support exacerbated the Russian states adherence to impractical economic schemes and dependency on oligarchs, as aid failed to be provided in sufficient quantities to reverse the declining situation in Russia.

\footnotetext{
${ }^{29}$ Anna Politkovskaya, A Russian Diary, trans. Arch Tait (London: Harvill Secker, 2007), 9.

30 Ziegler, History of Russia, 159.

${ }^{31}$ Nelson and Kuzes, Radical Reforms, 42-43.

32 Peter Passell, "Dr. Jeffrey Sachs, Shock Therapist," The New York Times, June 271993 , http:/ query.nytimes.com/gst/fullpage.html?res=9F0CE7D7143EF934A15755C0A965958260\&pagewanted= all, 2 .

33 Roy A Medvedev, Post Soviet Russia: A Journey Through the Yeltsin Era (New York: Columbia University Press, 2000), 15.

${ }^{34}$ Desai, Conversations on Russia, 101-102.

35 Ibid., 102.
} 
Eager to see Russia shed its communist past and embrace democracy and capitalism, the United States took the lead in supporting shock therapy's initiatives, and was heavily involved in securing financial aid for Russia. With political clout in the IMF, the United States was instrumental in negotiating billions of dollars of aid to remedy the Russian economy, yet infusions of foreign money created little economic growth, and often caused more problems than they solved. Pushing for mass privatization, the American influence on Russia's decision to rapidly sell state owned enterprises contributed to the formation of Russia's oligarch class. ${ }^{36}$ Pledging a $\$ 24$ billion dollar loan in 1992, the leadership of the United States was motivated more by fears of Russia's nuclear weapons instability and suppressing lingering communist elements in politics than assisting the people of Russia. ${ }^{37}$ Despite favorable opinions on Russia's marketization, IMF loans were not offered until August 1992, several months after shock therapy began, and after Yeltsin had resumed subsidizing industries to curb social unrest. Lent a modest $\$ 1$ billion by the IMF, loans to Russia during the tumultuous early months of shock therapy came too little, too late, while foreign investment failed to reach projected levels. ${ }^{38}$ Clearly, there would be no repeat of the Second World War's Marshall Plan, as Western nations preferred to work through the IMF than to risk direct involvement in Russia's unstable economy. ${ }^{39}$

Though initial conditions on loans were unrealistic, the IMF relaxed its requirements under pressure from the Clinton Administration. Through 1993-1994, billions more was transferred to Russia regardless of its economic or political progress, providing little motivation to meet IMF guidelines. Meanwhile, more aid flowing into the Russian economy and staunch American support for the Yeltsin government opened the door for corruption and embezzlement, leaving the Russian state massively indebted to its foreign benefactors. Fiscal responsibility remained elusive as US loans sustained inefficient government programs or financed misguided economic policies, impeding genuine reform. ${ }^{40}$

The coercion of the West in pushing for shock therapy, forcing Russia to tackle economic restructuring and state building simultaneously, obstructed independent legal and financial institutions from developing gradually. ${ }^{41}$ Uncoordinated efforts and conflicting opinions on the role of the international community, first being too stringent on loan conditions at the critical juncture of late 1991 through early 1992, then too lenient after shock therapy had strayed from its tenants, made the IMF and US government's contributions unproductive. In additions, many Russians, suspicious of foreign institutions, resented the influx of Western influence and their nation's fall from superpower to foreign dependency. ${ }^{42}$ IMF loan restrictions, stipulating budgetary restraint, could be traced to decreases in social spending, an effect felt most directly in Russians' declining standards of living. Disrupting Russia's ability to create a plan designed around its peculiar circumstances and failing to provide significant monetary resources to produce constructive results, the international community's role in shock therapy was problematic, undermining its ostensible intention of guiding the Russian state through its economic restructuring.

\footnotetext{
36 Shevtsova, Lost in Transition, 21.

37 Kramer, "Economic Complexion," 31.

${ }^{38}$ Kesselman, Comparative Politics, 324.

${ }^{39}$ Naomi Klein, Shock Doctrine: The Rise of Disaster Capitalism (Toronto: Random House, 2007), 298.

40 Kramer, "Economic Complexion," 28.

41 Peter Reddaway, "Instability and Fragmentation," Journal of Democracy 5.2 (1994): 15.

42 John Odling-Smee, "The IMF and Russia in the 1990s," IMF Staff Papers 53.1 (2006): 156.
} 


\section{Conclusion}

Undertaking rapid economic and political change at the same time, the policies of shock therapy left Russia a disoriented state. Institutionally weak, socially volatile, and hijacked by oligarchs, Yeltsin's reforms brought Russia to the verge of collapse. The last instance of such monumental change in Russian politics, the 1917 revolutions and short-lived Provisional government under Alexander Kerensky, ended with the Bolshevik takeover and 70 years of Communist rule. During shock therapy, it briefly appeared that past events might repeat themselves. Living with the memories of the Soviet past, the policies of shock therapy gave Russia the appearance of democracy and capitalism, while in reality it became a hybrid of authoritarianism and democracy, command and capitalism, past and present. Since 1998, the Russian economy has recovered, aided by rising natural resource prices and more competitive domestic production, securing the status of Vladimir Putin and the place of the Russian state in the economy. Bolstered by strong leadership and economic growth, Russia has resumed its place amongst the world's power elite, but cynicism about Yeltsin's contribution persists. The Yeltsin legacy remains inchoate, as the painful memories of shock therapy caused many Russians to consider whether free markets and democracy were in their country's best interest. Due to the relatively brief period of time that has passed and the fact that shock therapy's upheavals still reverberate through social and economic circles, scholarship on the Yeltsin era has yet to promulgate a definitive conclusion. However, a general consensus about the impracticality of Yeltsin's program which essentially enacted change too liberally and too quickly has found scholarly consensus. The answers to these questions are still being worked out, and will undoubtedly be revised by future historians as Russia's natural resources, the catalyst for its current prosperity, begin to expire. 


\section{Bibliography}

Colton, Timothy J. Yeltsin: A Life. New York: Basic Books, 2008.

Desai, Padma. "Beyond Shock Therapy.” Journal of Democracy 6.2 (1995): 102-112. Conversations on Russia: Reform from Yeltsin to Putin. New York: Oxford University Press, 2006.

Ellison, Herbert J. Boris Yeltsin and Russia's Democratic Transformation. Seattle: University of Washington Press, 2006.

Gidadhubli, R.G. and Arun Mohanty. "Continuing Debate over 'Shock Therapy." Economic and Political Weekly 37.50 (2002): 4998-5002.

Kesselman, Mark et al., Introduction to Comparative Politics: Global North Custom Edition. Boston: Wadsworth, 2010.

Klein, Naomi. Shock Doctrine: The Rise of Disaster Capitalism. Toronto: Random House, 2007.

Kramer, Mark. "The Changing Economic Complexion of Eastern Europe and Russia: Results and Lessons of the 1990s." SAIS Review 19.2 (1999): 16-45.

"Mass Murder and the Market" The Economist, 22 Jan 2009: http://www.economist.com/node/12972677 > (accessed 22 March 2011).

Marples, David. "Russia Emerges From The Ruins.” University of Alberta lecture, Edmonton. 2 March 2011.

Medvedev, Roy A. Post Soviet Russia: A Journey Through the Yeltsin Era. New York: Columbia University Press, 2000.

Nelson, Lynn D. and Irina Y. Kuzes. Radical Reforms In Yeltsin's Russia: Political, Economic, and Social Dimensions. New York: M.E. Sharpe, 1995.

Odling-Smee, John. "The IMF and Russia in the 1990s.” IMF Staff Papers 53.1 (2006): 151-194.

Orenstein, Mitchell. "Lawlessness From Above and Below: Economic Radicalism and Political Institutions." SAIS Review 18.1 (1998): 35-50.

Passell, Peter. "Dr. Jeffrey Sachs, Shock Therapist.” The New York Times, 27 June 1993. http:/ /query.nytimes.com/gst/ fullpage.html?res=9F0CE7D7143EF934A15755C0A9659 58260\&pagewanted=all> (accessed 23 March 2011).

Politkovskaya, Anna. A Russian Diary, trans. Translated by Arch Tait. London: Harvill Secker, 2007.

Reddaway, Peter. "Instability and Fragmentation." Journal of Democracy 5.2 (1994): 13-19.

Schmemann, Serge. "Yeltsin Is Telling Russians To Brace For Sharp Reform." The New York Times, October 29, 1991.

Shevtsova, Lilia. Russia-Lost in Transition: The Yeltsin and Putin Legacies. Washington, DC: Carnegie Endowment for International Peace, 2007.

-------. Yeltsin's Russia: Myths and Reality. Washington: Carnegie Endowment for International Peace, 1999.

Ziegler, Charles E. The History of Russia. 2nd ed. California: Greenwood Press, 2009. 